\title{
Correction to: Role of the triad of procalcitonin, C-reactive protein, and white blood cell count in the prediction of anastomotic leak following colorectal resections
}

\author{
Haidi Abd El Zaher ${ }^{1 \dagger}$, Waleed M. Ghareeb ${ }^{2,3^{*}+}$, Ahmed M. Fouad ${ }^{4}$, Khaled Madbouly ${ }^{5^{*}}$, Hamada Fathy ${ }^{1}$, \\ Tomas Vedin ${ }^{6}$, Marcus Edelhamre ${ }^{6}$, Sameh H. Emile ${ }^{7 *}$ and Mohammed Faisal ${ }^{1,8}$
}

Correction to: World J Surg Oncol 20, 33 (2022)

https://doi.org/10.1186/s12957-022-02506-4

Following the publication of the original article [1], the affiliation of the 3rd author named Ahmed M. Fouad was written wrongly as

4 Department of Public Health, Community Medicine, Occupational \& Environmental Medicine, Faculty of Medicine, Suez Canal University, Fuzhou, China,

It should be

4 Department of Public Health, Community Medicine, Occupational \& Environmental Medicine, Faculty of Medicine, Suez Canal University, Ismailia, Egypt .

In the Authors contribution section, „HA, HF, AF, and WMG carried out the study and analyzed the data" should be „HA, HF, AF, MF and WMG carried out the study and analyzed the data"

The original article has been updated.

\begin{abstract}
Author details
${ }^{1}$ Surgical Oncology Unit, Department of Surgery, Faculty of Medicine, Suez Canal University Hospital, Ismailia, Egypt. ${ }^{2}$ Gastrointestinal Surgery Unit, Department of Surgery, Faculty of Medicine, Suez Canal University Hospital, Ismailia, Egypt. ${ }^{3}$ Faculty of Medicine, Suez Canal University, Ismailia, Egypt. ${ }^{4}$ Department of Public Health, Community Medicine, Occupational \& Environmental Medicine, Faculty of Medicine, Suez Canal University, Ismailia, Egypt. ${ }^{5}$ Colorectal Surgery Unit, Alexandria University, School of Medicine, Alexandria, Egypt. ${ }^{6}$ Department of Surgery, Helsingborg Hospital, University of Lund, 251 87 Helsingborg, Sweden. ${ }^{7}$ Colorectal Surgery Unit, General Surgery Department, Mansoura University Hospital, Mansoura, Egypt. ${ }^{8}$ General Surgery Department, Sahlgrenska University Hospital, Gothenburg, Sweden.
\end{abstract}

Published online: 01 March 2022

\section{Reference}

1. El Zaher HA, Ghareeb WM, Fouad AM, et al. Role of the triad of procalcitonin, C-reactive protein, and white blood cell count in the prediction of anastomotic leak following colorectal resections. World J Surg Onc. 2022;20:33. https://doi.org/10.1186/s12957-022-02506-4.

*Correspondence: waleed.m.ghareeb@med.suez.edu.eg; khaled. madbouly@alexmed.edu.eg; sameh200@hotmail.com

${ }^{\dagger}$ Haidi Abd El Zaher and Waleed M. Ghareeb contributed equally to this work.

${ }^{3}$ Faculty of Medicine, Suez Canal University, Ismailia, Egypt

${ }^{5}$ Colorectal Surgery Unit, Alexandria University, School of Medicine, Alexandria, Egypt

${ }^{7}$ Colorectal Surgery Unit, General Surgery Department, Mansoura University Hospital, Mansoura, Egypt

Full list of author information is available at the end of the article

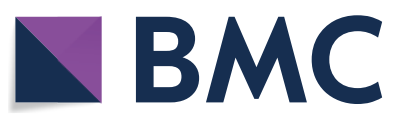

(c) The Author(s) 2022. Open Access This article is licensed under a Creative Commons Attribution 4.0 International License, which permits use, sharing, adaptation, distribution and reproduction in any medium or format, as long as you give appropriate credit to the original author(s) and the source, provide a link to the Creative Commons licence, and indicate if changes were made. The images or other third party material in this article are included in the article's Creative Commons licence, unless indicated otherwise in a credit line to the material. If material is not included in the article's Creative Commons licence and your intended use is not permitted by statutory regulation or exceeds the permitted use, you will need to obtain permission directly from the copyright holder. To view a copy of this licence, visit http://creativecommons.org/licenses/by/4.0/. The Creative Commons Public Domain Dedication waiver (http://creativeco mmons.org/publicdomain/zero/1.0/) applies to the data made available in this article, unless otherwise stated in a credit line to the data. 